Review

\title{
Disposable over Reusable Face Masks: Public Safety or Environmental Disaster?
}

\author{
Joana C. Prata ${ }^{1, *,+(\mathbb{D})}$, Ana L. Patrício Silva ${ }^{2,+(\mathbb{D})}$, Armando C. Duarte ${ }^{1}$ and Teresa Rocha-Santos ${ }^{1}$ (D) \\ 1 Centre for Environmental and Marine Studies (CESAM) \& Department of Chemistry, University of Aveiro, \\ 3810-193 Aveiro, Portugal; aduarte@ua.pt (A.C.D.); ter.alex@ua.pt (T.R.-S.) \\ 2 Centre for Environmental and Marine Studies (CESAM) \& Department of Biology, University of Aveiro, \\ 3810-193 Aveiro, Portugal; ana.luisa.silva@ua.pt \\ * Correspondence: pratajc@ua.pt \\ + These authors contributed equally to this work.
}

Citation: Prata, J.C.; Silva, A.L.P.;

Duarte, A.C.; Rocha-Santos, T.

Disposable over Reusable Face Masks:

Public Safety or Environmental

Disaster? Environments 2021, 8, 31.

https://doi.org/10.3390/environments 8040031

Academic Editors: Göran Finnveden and Dimitrios Komilis

Received: 22 February 2021

Accepted: 11 April 2021

Published: 13 April 2021

Publisher's Note: MDPI stays neutral with regard to jurisdictional claims in published maps and institutional affiliations.

Copyright: (c) 2021 by the authors. Licensee MDPI, Basel, Switzerland. This article is an open access article distributed under the terms and conditions of the Creative Commons Attribution (CC BY) license (https:// creativecommons.org/licenses/by/ $4.0 /)$.

\begin{abstract}
Many governments have imposed the public use of face masks and they are now moving towards enforcing disposable masks to abate COVID-19 transmission. While disposable masks consistently provide higher protection, they also carry multiple environmental burdens, from greenhouse gases released during production to the landfilling and littering. Conversely, reusable masks' protection can vary from $>90 \%$ certified industrial masks, similar to disposable masks, to dubious homemade or artisanal masks. This work discusses the protection provided by different masks, their impact on the environment, and new proposals combining concerns about public health and sustainability.
\end{abstract}

Keywords: SARS-CoV-2; personal protective equipment (PPE), cloth masks; fabric masks; surgical masks; medical masks; respirators

\section{Introduction}

The COVID-19 pandemic, transmitted by respiratory droplets [1], increased the global demand for face masks (herein masks) used by healthcare professional and the general population as a measure to reduce viral transmission, in pair with social distancing and hygiene. Depending on cultural and economic factors, disposable or reusable masks have been voluntarily or compulsory adopted by the public [2]. Disposable masks refer to loose-fitting surgical masks and well-fitted respirators (e.g., N95) with filtration efficiencies characterized as FFP1 (80\%), to FFP2 (94\%), and FFP3 (99\%) in Europe and N95 (95\%), to N99 (99\%), and N100 (100\%) in the US [3]. Disposable masks are made of polypropylene (PP) and high-density polyethylene (HDPE) used in the production of nonwoven fabrics using a melt-blown process [4,5]. Some of these FFP devices are classified as reusable (marked with "R") [6]. Conversely, reusable textile masks are highly available at lowcost, varying in quality from homemade or artisanal, to industrial productions subjected to certification. However, the rise in virus variants with increased transmissibility [7] raised concerns over the public use of reusable masks, considering the wide variation in protection efficiency. For instance, only $20 \%$ of over 3000 certified reusable masks in Portugal had filtration efficiencies $>90 \%$ [8]. Facing these new strains while attempting to avoid economic disruption caused by lockdowns and the overloading of public health systems, many countries (e.g., France, Austria, and Germany) are enforcing the use of disposable masks in numerous public spaces [9]. Restrictions on the use of reusable masks in public spaces have not considered their diversity and variable protection. Considering the estimated global use of 129 billion disposable masks per month [10], it is urgent to understand the scientific foundations supporting the use of disposable over reusable masks, the repercussions of these measures, and potential workarounds which can favor sustainability without compromising public health. This manuscript provides an overview on protection efficiency, environmental impacts, and recommendations on disposable and reusable masks for public use. 


\section{Protection Efficiency of Disposable and Reusable Masks}

Transmission of SARS-CoV-2 mainly occurs through airborne droplets $(5-10 \mu \mathrm{m})$ and aerosols $(\leq 5 \mu \mathrm{m})$, including from asymptomatic individuals or before the onset of disease [11]. Masks can reduce the release of particles and protect the wearer [11]. After a first stage of global personal protective equipment (PPE) shortage, public use of masks has been recommended or enforced in several countries to prevent community transmission of SARS-CoV-2 virus [12]. Indeed, no coronavirus could be detected in respiratory droplets and aerosols of patients wearing surgical masks compared to $30-40 \%$ of samples of patients without masks [13]. Community mask use to reduce COVID-19 transmission is supported by a study following over 300,000 individuals in the US [14] and reduced household transmission in Beijing, China [15]. While mask use became the norm, the protection provided by different solutions has only recently attracted governmental attention.

Studies on the efficiency and protection conferred by masks are conducted in three major types: reusable (or cloth) masks, surgical masks, and respirators. For Influenza virus, also transmitted by respiratory droplets and aerosols, both respirators (N95) and surgical masks were effective in preventing the spread of the virus from infected patients [16] and in preventing infection of healthcare workers working in outpatient settings [17]. While all masks are protective for Influenza, homemade masks produced from tea clothes provided two times less protection than surgical masks and 50 times less than FFP2 respirators [18]. Similarly, surgical masks presented better filtration efficiency and generally reduced the total amount of microorganisms expelled by coughing, compared to homemade masks of different materials [19]. For COVID-19, a surgical mask barrier significantly reduced transmission or produced fewer clinical manifestations in Golden Syrian Hamster [20]. The Centers for Disease Control and Prevention (CDC) recommends general use of cloth masks, ideally of multiple layers of high-thread-count textiles, which can block up to $50-70 \%$ of fine droplets and particles and are reported to reduce transmission in multiple settings [21]. However, a metanalysis of betacoronavirus (including SARS-CoV-2) concludes that, while all masks are effective at preventing transmission, respirators (e.g., N95) are more protective than disposable medical masks or reusable cotton masks (12-16 layers) [22]. In summary, all masks can contribute to the reduction of COVID-19 transmission, but higher protection can be achieved by using respirators, followed by surgical masks, and finally reusable or cloth masks.

Compared to no mask, a modeling study showed that even moderately effective masks $(50 \%)$ worn by $80 \%$ of the population could prevent $17-45 \%$ of deaths over 2 months in New York, US [23]. Thus, reusable masks, even if moderately effective, can be a useful tool to control the pandemic, especially when coupled with social distancing and hand hygiene. Moreover, most works have not considered the diversity of reusable masks available in regard to their quality. Recommendations regarding homemade mask making include selection of proper fabrics, using multiple layers $(>2-3)$, choosing a design with a proper seal around the face, and using fitting ear loops [24]. A review on cloth masks found that, generally, textiles $>300$ TPI (threads per inch) had filtration efficiencies above $80 \%$ and recommends the use of cotton or flannel of at least 100 TPI in at least two layers [25]. Well-fitted multilayer masks combining a layer of 600 TPI cotton with two layers of silk, two layers of chiffon, or one layer of flannel, by providing physical and electrostatic filtering, produced efficiencies of $>90 \%$, comparable to those achieved by N95 respirators [26]. Additionally, humidity released by breathing (i.e., $99 \%$ relative humidity) increases particle capture in $100 \%$ cotton fabrics, increasing filtration efficiency by $63 \%$ for $825 \mathrm{~nm}$ particles [27]. These characteristics should also be tested in terms of wearability, such comfort, breathing effort, and thermal conductivity, to ensure extended use without removal [28]. Thus, reusable masks can provide effective and reliable protection comparable to disposable masks if produced following rigid quality standards. Testing standards for disposable masks can be applied to reusable masks (e.g., EN 14683:2019+AC:2019; see Reference [29]). Moreover, certified reusable masks generally have efficiencies of filtration of $3 \mu \mathrm{m}$ particles $>70 \%$ or $>90 \%$-in the last case, similar to surgical masks [30]. 
The efficiency of masks also depends on their correct use. Reusable masks may be subjected to longer periods of use, multiple reuses without cleaning, ineffective cleaning procedures, or decreased protection by exceeding the recommended number of washings. Similarly, disposable masks, which should be used for 3-4 h, can be used for longer periods, improperly stored (e.g., in pockets), and reused. For both, incorrect use and manipulation can increase the risk of transmission. Besides filtration efficiency and use, the design of both disposable and reusable masks should reduce face-seal leakage (i.e., by proper sealing around the face), preventing the inward leakage of ambient aerosols and thus exposure to infectious agents. For instance, N95 respirators present lower inward leakage compared to generally loose-fitting surgical masks [31]. Face-seal leakage highly influences mask performance, which is not often accounted for when assessing the efficiency of facemask materials, with increased ventilation resistance and mask gap dimensions hindering protection (e.g., gaps of $1.5 \%$ of mask area can result in a $20 \%$ bypass of unfiltered air) [32]. Therefore, both disposable and reusable masks should be designed to reduce face-seal leakage. Reusable masks have the additional problem of including homemade or artisanal masks with varying efficiencies and not complying with quality standards. When it comes to selecting face masks, design and fashion of reusable masks often outweigh functionally in the consumer's eyes. Additionally, reusable masks may be preferred by lower income families due to their low-cost, as they can be 3.7 times cheaper than disposable masks [33]. In Portugal, the monthly cost of wearing two FFP2 masks per day (0.7-1.9€, [34]) is 42-114€ per person. Therefore, the obligatory use of FFP2 masks increases social injustices in the access to public and workspaces, while further straining the budget of low-income families.

\section{Environmental Impact of Disposable and Reusable Masks}

Reusable masks have been recommended as safe and ecofriendly alternatives [35], with the implementation of the obligatory use of disposable masks worsening environmental problems, from production to disposal. However, the environmental impact of reusable masks relies on their type and the use behavior and mask choice by common citizens (i.e., reusability, times of reuse, type of washing, and use of filters or not). For instance, in an estimation based on UK yearly use of masks, Allison et al. [33] reported similar environmental footprint between of reusable masks to the surgical masks, when considering the use of filters and manual washing of reusable masks $\left(\approx 1.50 \times 10^{9} \mathrm{~kg} \mathrm{CO}_{2}\right.$ eq), but lower in reusable masks without filters and machine washed $\left(1.7 \times 10^{8} \mathrm{~kg} \mathrm{CO}_{2} \mathrm{eq}\right)$. Conversely, reusable masks without filters and machine-washed have a greater water use than disposable masks, due to the washing process $\left(7.5 \times 10^{8}\right.$ vs. $\left.1.4 \times 10^{8} \mathrm{~m}^{3}\right)$. Greenhouse gas (GHG) emissions of producing cotton cloth masks are similar to surgical masks $(\sim 0.06$ $\mathrm{kg} \mathrm{CO} 2 \mathrm{eq} / \mathrm{pcs}$ ), but increases to $6.92 \mathrm{~kg} \mathrm{CO}_{2} \mathrm{eq} / \mathrm{pcs}$ considering washing (as reviewed by Reference [36]). However, the estimation of cotton cloth masks has not considered the transportation emission that is accounted for surgical masks. However, if a reusable mask could be used for 183 times (without the use of disposable filters and considering cleaning in the washing machine with regular clothes), the environmental footprint would go down to $0.04 \mathrm{~kg} \mathrm{CO}_{2}$ eq [36]. However, the cumulative effects of washing can contribute to the degradation of the mask material and reduced protection. Reusable masks can be made of synthetic materials (e.g., polyester), which can reduce emissions and improve the number of reuses. In addition, an adequate use and cleaning of reusable masks seems to reduce waste by $85 \%$ and have a lower impact on climate change by 3.5 times, while also being 3.7 times cheaper [33]. However, information regarding fiber release during washing and their final disposal is still lacking [37]. After use, both disposable or reusable masks should be disposed of as municipal solid waste, ideally double-bagged, to be preferably incinerated or landfilled [38]. Alternatively, a new waste stream can be created to collect and treat PPE, reducing the amount of litter requiring treatment [39]. While incineration $\left(800-1000{ }^{\circ} \mathrm{C}\right)$ decontaminates waste, with potential for energy production, these infrastructures may already be overburdened by the growing medical waste [40]. Most COVID-19 household waste is being landfilled [41] or, worse, discarded in open landfills in countries with limited 
resources for proper waste management (e.g., Thailand, Philippines, and India), creating both an environmental and public health problems [42]. In addition to the release of greenhouse gases, landfilling of wastes may generate microplastics which are present in landfill leachates and may be released to the surrounding environment [43]. In landfills' anaerobic environments, plastics from masks degrade forming microplastics due to variations in temperature and $\mathrm{pH}$, physical stress, and competitions, as well as action of microbiological activity, which contributes to a progressive degradation and formation of microplastics [43], while degradation in open dumps occurs from sunlight exposure and methanotrophic microorganisms' activity at a faster rate than in soil $[44,45]$. Recycling of PPE is challenging because it may require previous decontamination (e.g., by UV light; see Reference [46]) and because items are composed of multiple polymer types which cannot be easily separated by routine grinding and remelting. Other recycling solutions can be applied to masks, such as in the production of thermoset composites, using a crosslinking compatibilizer agent to overcome the presence of multiple polymer types [47] or by thermal-recycling producing feedstock containing useful chemicals or liquid fuels, which then can be used in the production of other materials or as energy $[48,49]$. These solutions could pair public health measures with the progression towards a circular economy less reliant on landfilling.

In addition to challenges posed by waste management, many masks are littered and released directly to the environment (Figure 1). In Morocco, 9\% of survey respondents admitted to disposing of masks in public spaces [50], while littered PPE dominated by

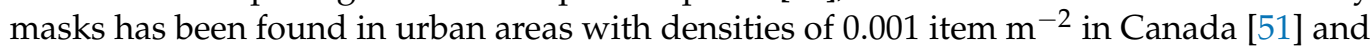
$<0.3$ item $\mathrm{m}^{-2}$ in Kenya [52]. While densities are dependent on sampling areas (e.g., higher concentrations can be found near hospitals, [51]), littered items can vary with culture, with disposable masks being a less relevant category of COVID-related litter in South Africa, due to the widespread use of reusable cotton masks [2]. Beaches, which improved in quality at the beginning of the pandemic [53], are now tainted with PPE, with this category comprising up to $55.1 \%$ of anthropogenic beach litter in urban beaches in Kenya [52]. Conversely, this litter is not found in coastal surface trawls, suggesting preferential accumulation on beaches or the seabed after sinking [52]. PPE is also transported by rivers, comprising $16.0 \%$ of items in Jakarta rivers from March to April of 2020, with a high predominance of facemasks (9.8\%) [54]. Moreover, urban infrastructures are being burdened by PPE, with littering and incorrect disposal into wastewater systems increasing maintenance costs by $\$ 250$ million a year in Canada [55]. The fate of littered PPE depends on their characteristics in the environment, varying with brands and products, such as polymer density [56]. Degradation of nonwoven materials is likely to generate synthetic micro- and nanofibers when exposed to environmental conditions [56], as fibers are released during mask use and even potentially inhaled [57]. In the environment, weathering of plastics mainly occurs by photo-oxidation by exposure to solar UV radiation, and at a slower rate by biodegradation and hydrolysis, while posterior mechanical forces can lead to the formation of cracks and fragmentation or delamination of smaller pieces, originating microplastics which accumulate in the environment [58]. While larger plastics can lead to entanglement and starvation after ingestion, microplastics can cause oxidative stress originating mortality, reproductive failure, and decrease growth and feeding, in addition to being vectors to other contaminants and microorganisms, having a negative impact on ecosystems [59]. 


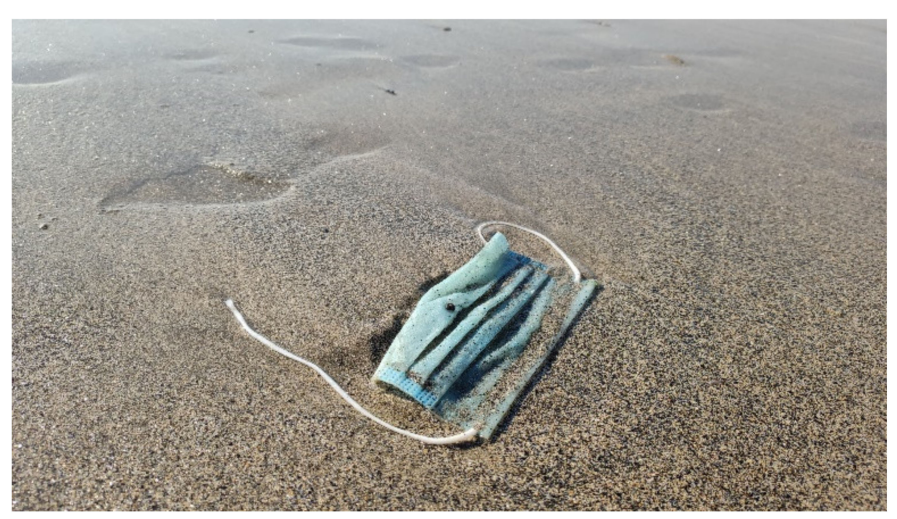

(a)

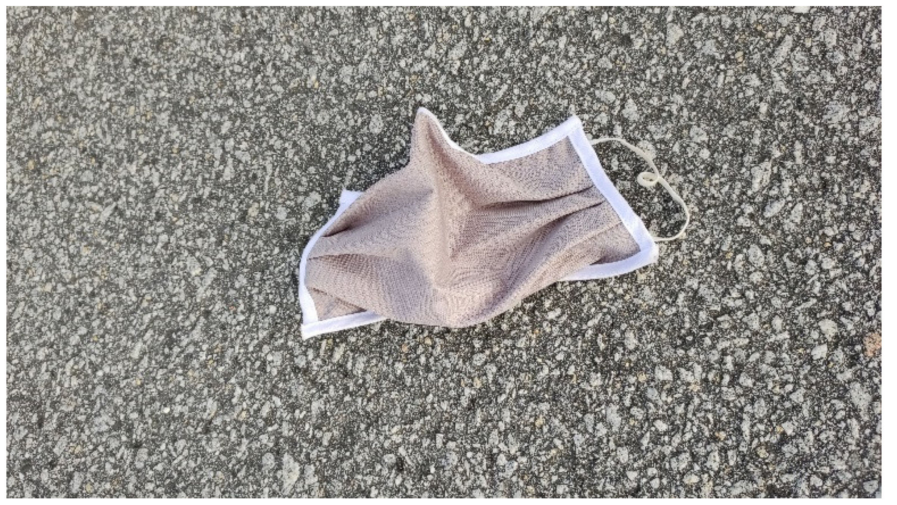

(b)

Figure 1. Incorrect disposal of masks observed in Portugal: (a) disposable masks on a beach and (b) reusable mask on an urban street.

\section{Recommendations on the Use of Disposable and Reusable Masks}

As previously discussed, surgical masks and respirators consistently performed better than tested reusable masks. While this supports the phasing of reusable masks, performance and reliability also varies within categories (i.e., from artisanal to certified industrial reusable masks), and many misuses are shared with disposable masks (e.g., multiple reuses). Disposable masks present environmental challenges, from the release of greenhouse gases during production, to the amount of waste generated or littering of public spaces. Reusable masks are also not devoid of environmental impacts, depending on their type and consumption patterns. Considering that both choices have different consequences, favoring disposable or reusable masks falls over the priorities determined by governments. More information on day-to-day protection provided by disposable and reusable masks, conditioned by their correct use (e.g., correct face seal and proper washing), as well as the specific environmental impacts for each type and scenario (e.g., depending on waste treatment; microplastic release during use, washing, and disposal) can clarify the pros and cons of each mask type. Nonetheless, various strategies can be adopted to couple public health with long-term environmental sustainability:

- Reusable masks can be produced to achieve protection efficiencies $>90 \%$, similar to disposable masks (e.g., by using specific fabric combinations to enhance electrostatic and physical filtering [26]). In Portugal, $20 \%$ of certified reusable masks already provide protection $>90 \%$ [8], proving that it is possible to achieve high protection efficiencies. Additionally, face-seal leakage should be reduced in any mask by including metal nose and face pinches [60], applying a thermoplastic rings or braces over the mask [61,62], simply by knotting the ear loops [62], or improving design. Moreover, color-changing sensors can be used to reduce the misuse of reusable masks. For instance, photochromic systems can monitor the length of use of the masks by reversibly developing color when exposed to light, while thermochromic systems can be used to monitor proper decontamination under high temperatures, by fading color [63]. Additionally, antiviral materials (e.g., with non-adhesive surfaces or nanostructures), capable of eliminating the virus on their surfaces while being safe for the wearer, can also be developed and applied to improve the protection provided by reusable masks [64]. Masks capable of inactivating SARS-CoV-2 and which retain their efficiencies after 50 washes are already being commercialized in Portugal [65]. Reusable masks following these manufacturing recommendations can be considered equivalent to disposable masks, but they are still dependent on correct use and cleaning. However, the implementation of novel technologies on reusable masks should be accompanied by the evaluation of environmental footprint. To reduce the environmental footprint of cotton reusable masks, its major component should be cotton that is rain-fed (there- 
fore lowering the water footprint) or organically grown cotton (lowering the carbon footprint in the absence of pesticides and fossil fertilizers). Another solution could be the use of recycled cotton, or other types of materials, such as polyester. An increase in lifespan, a decrease in weight, and machine-washing procedures for cleaning (rather than handwashing) can also reduce the environmental footprint of reusable masks. Furthermore, the environmental impact of reusable masks (and general PPE) could be reduced by increasing local manufacture (rather than importing/shipping supplies) and by rationalizing their use and cleaning processes. Moreover, safe reusable masks design must appeal to consumers to discourage the use of artisanal masks.

- Production of disposable masks may follow more sustainable practices to offset their environmental impacts. These include the use of plastics produced from renewable resources, the use of renewable energy in the manufacturing and transportation, and proper disposal. As an example, a successful filtering media has been of wheat gluten biopolymer, a by-product of the food industry [66]. However, cost and scaling of biorefineries may limit these novel applications in the short-term [67]. Specific life-cycle assessments can be created to assess and mitigate environmental impacts. Disposable masks can also be reused after proper decontamination treatments while maintaining protection efficiency, further reducing environmental impacts. For instance, decontamination of $\mathrm{N} 95$ masks can be achieved by steaming without loss of protection [68]. Reuse of disposable masks could help decrease their environmental footprint and cost.

- Reusable masks should be subjected to standardization similar to disposable masks. For instance, they could follow the same ASTM Standards [69] or require full certification regarding their efficacy over a known number of washings, which may be found in a national list (e.g., see Reference [70]). Standardization should also include face-seal leakage requirements for both disposable and reusable masks. The use of non-approved masks must be discouraged, which may vary from public awareness to banning this practice by applying fines to their wearers or sellers. To ensure compliance, a certification mark can be included in a visible area of the mask. In addition, all manufacturers should provide information about the materials used in each layer (composition, weave, weight, and thread count), the number of layers [25], and faceseal leakage. Recommendations regarding decontamination must also be provided.

- Instead of generally enforcing the use of disposable masks, these can be specially enforced only in high-risk situations, such shared indoor environments (e.g., hospitals, offices, shops, and markets), while maintaining reusable masks in lower-risk situations (e.g., walking outside). For instance, in Austria, FFP2 masks are already required in transit, businesses, market, and carpooling [9]. Similarly, the World Health Organization recommends reusable masks, except in suspected cases, those caring for COVID-19 infected, people over 60, and those with underlying conditions which increase risk [71]. Moreover, the effects of the widespread use of disposable masks on daily incidence of disease in specific situations can be modeled, maximizing their benefits.

- When implementing the obligatory use of disposable masks, and considering their higher costs, availability in stores and equal access must be guaranteed, especially for lower-income families. Otherwise, this measure can increase social injustices. State co-payment, such as often applied to pharmaceutical products, can be implemented in these cases, considering the importance of masks for public health. For instance, people over 60 or with chronic conditions in Germany will receive FFP2 masks [9]. Besides medical-risk groups, low-income families should also receive masks.

- Masks and other PPEs should be collected in proper containers for end-of-life repurposing or incineration. Collection can be made in sealed specific-colored bags for door-to-door collection or in specific bins distributed in public places, allowing for separation and specific treatment [39]. PPE-bins have already been installed in Montreal, Canada, and in Guimarães, Portugal [72,73]. Separation also allows for specific treatment (e.g., incineration and recycling) of PEE waste. 
- Recycling of disposable masks can be achieved by thermo-recycling $[48,49]$ or by producing composites (e.g., conducted by companies such TerraCycle and UBQ Materials; see References [74,75]). When recycling is not feasible, incineration is preferred since it eliminates pathogens and avoids landfilling. Due to the large amount of waste requiring incineration (e.g., medical waste), countries may need to increase their treatment capacity, either by involving private companies or having backup incinerators, or at least having sufficient waste-storage spaces.

- Public awareness and education can provide tools on the proper use and disposal of masks. Awareness programs can support the use of certified reusable masks and their proper decontamination. Additionally, it may encourage the correct disposal of masks after use and advertising for the public health and environmental dangers of incorrect disposal of masks. Targeted actions may be applied to areas where the incorrect disposal of masks is more likely to happen (e.g., near hospitals and grocery shops; see Reference [51]).

Author Contributions: J.C.P., conceptualization, project administration, visualization, writingoriginal draft, and writing-review and editing. A.L.P.S., conceptualization, project administration, visualization, writing—original draft, and writing—review and editing. A.C.D., supervision, project administration, funding acquisition, and writing - review and editing. T.R.-S., conceptualization, supervision, project administration, funding acquisition, and writing-review and editing. All authors have read and agreed to the published version of the manuscript.

Funding: Thanks are due to FCT/MCTES for the financial support (UIDP/50017/2020+UIDB/50017/2020), through national funds. This work was also funded by Portuguese Science Foundation (FCT), through the scholarship PD/BD/135581/2018 and the research contract CEECIND/01366/2018, under POCH funds, co-financed by the European Social Fund and Portuguese National Funds from MEC.

Conflicts of Interest: The authors declare no conflict of interest.

\section{References}

1. Tay, M.Z.; Poh, C.M.; Rénia, L.; MacAry, P.A.; Ng, L.F.P. The trinity of COVID-19: Immunity, inflammation and intervention. Nat. Rev. Immunol. 2020, 20, 363-374. [CrossRef] [PubMed]

2. Ryan, P.G.; Maclean, K.; Weideman, E.A. The Impact of the COVID-19 Lockdown on Urban Street Litter in South Africa. Environ. Process. 2020, 7, 1303-1312. [CrossRef]

3. Czigány, T.; Ronkay, F. The coronavirus and plastics. eXPRESS Polym. Lett. 2020, 14, 510-511. [CrossRef]

4. Chua, M.H.; Cheng, W.; Goh, S.S.; Kong, J.; Li, B.; Lim, J.Y.C.; Mao, L.; Wang, S.; Xue, K.; Yang, L.; et al. Face Masks in the New COVID-19 Normal: Materials, Testing, and Perspectives. Research 2020, 2020, 7286735. [CrossRef]

5. Fadare, O.O.; Okoffo, E.D. Covid-19 face masks: A potential source of microplastic fibers in the environment. Sci. Total Environ. 2020, 737, 140279. [CrossRef]

6. International Council of Certification. EUROPEAN STANDARD UNI EN 149:2001+A1:2009 FACEMASKS. Available online: https:/ /icc-iso.org/index.php/en/certificates/58-maskat-en (accessed on 9 February 2021).

7. SARS-CoV-2 Variants. Available online: https://www.who.int/csr/don/31-december-2020-sars-cov2-variants/en/ (accessed on 9 February 2021).

8. Ferreira, V.; de Freitas, I.D. Oitenta por cento das máscaras certificadas pela indústria não cumprem novas normas europeias. Eighty percent of certified masks do not comply with new European norms. Publico, 28 January 2021.

9. Some European Countries Move to Require Medical-Grade Masks in Public. Available online: https://www.npr.org/sections/ coronavirus-live-updates/2021/01/26/960893423/some-european-countries-move-to-require-medical-grade-masks-inpublic (accessed on 9 February 2021).

10. Prata, J.C.; Silva, A.L.P.; Walker, T.R.; Duarte, A.C.; Rocha-Santos, T. COVID-19 Pandemic Repercussions on the Use and Management of Plastics. Environ. Sci. Technol. 2020, 54, 7760-7765. [CrossRef] [PubMed]

11. Prather, K.A.; Wang, C.C.; Schooley, R.T. Reducing transmission of SARS-CoV-2. Science 2020, 368, 1422-1424. [CrossRef]

12. Patrício Silva, A.L.; Prata, J.C.; Walker, T.R.; Campos, D.; Duarte, A.C.; Soares, A.M.V.M.; Barcelò, D.; Rocha-Santos, T. Rethinking and optimising plastic waste management under COVID-19 pandemic: Policy solutions based on redesign and reduction of single-use plastics and personal protective equipment. Sci. Total Environ. 2020, 742, 140565. [CrossRef]

13. Leung, N.H.L.; Chu, D.K.W.; Shiu, E.Y.C.; Chan, K.-H.; McDevitt, J.J.; Hau, B.J.P.; Yen, H.-L.; Li, Y.; Ip, D.K.M.; Peiris, J.S.M.; et al. Respiratory virus shedding in exhaled breath and efficacy of face masks. Nat. Med. 2020, 26, 676-680. [CrossRef] 
14. Rader, B.; White, L.F.; Burns, M.R.; Chen, J.; Brilliant, J.; Cohen, J.; Shaman, J.; Brilliant, L.; Kraemer, M.U.G.; Hawkins, J.B.; et al. Mask-wearing and control of SARS-CoV-2 transmission in the USA: A cross-sectional study. Lancet Digit. Health 2021, 3, 148-157. [CrossRef]

15. Wang, Y.; Tian, H.; Zhang, L.; Zhang, M.; Guo, D.; Wu, W.; Zhang, X.; Kan, G.L.; Jia, L.; Huo, D.; et al. Reduction of secondary transmission of SARS-CoV-2 in households by face mask use, disinfection and social distancing: A cohort study in Beijing, China. BMJ Glob. Health 2020, 5, e002794. [CrossRef]

16. Johnson, D.F.; Druce, J.D.; Birch, C.; Grayson, M.L. A Quantitative Assessment of the Efficacy of Surgical and N95 Masks to Filter Influenza Virus in Patients with Acute Influenza Infection. Clin. Infect. Dis. 2009, 49, 275-277. [CrossRef] [PubMed]

17. Radonovich, L.J.; Simberkoff, M.S.; Bessesen, M.T.; Brown, A.C.; Cummings, D.A.T.; Gaydos, C.A.; Los, J.G.; Krosche, A.E.; Gibert, C.L.; Gorse, G.J.; et al. N95 Respirators vs. Medical Masks for Preventing Influenza Among Health Care Personnel. JAMA 2019, 322, 824. [CrossRef]

18. van der Sande, M.; Teunis, P.; Sabel, R. Professional and Home-Made Face Masks Reduce Exposure to Respiratory Infections among the General Population. PLoS ONE 2008, 3, e2618. [CrossRef]

19. Davies, A.; Thompson, K.-A.; Giri, K.; Kafatos, G.; Walker, J.; Bennett, A. Testing the Efficacy of Homemade Masks: Would They Protect in an Influenza Pandemic? Disaster Med. Public Health Prep. 2013, 7, 413-418. [CrossRef]

20. Chan, J.F.-W.; Yuan, S.; Zhang, A.J.; Poon, V.K.-M.; Chan, C.C.-S.; Lee, A.C.-Y.; Fan, Z.; Li, C.; Liang, R.; Cao, J.; et al. Surgical Mask Partition Reduces the Risk of Noncontact Transmission in a Golden Syrian Hamster Model for Coronavirus Disease 2019 (COVID-19). Clin. Infect. Dis. 2020, 71, 2139-2149. [CrossRef]

21. Scientific Brief: Community Use of Cloth Masks to Control the Spread of SARS-CoV-2. Available online: https: / /www.cdc.gov / coronavirus / 2019-ncov/more/masking-science-sars-cov2.html?fbclid=IwAR28PppCa6\$ $\backslash$ times $\$ 2$ uxwO8Z2baHM0KHS4JXx0 inzzMQs3zRHV1qq1_0a8mxZfpCw (accessed on 9 February 2021).

22. Chu, D.K.; Akl, E.A.; Duda, S.; Solo, K.; Yaacoub, S.; Schünemann, H.J.; Chu, D.K.; Akl, E.A.; El-harakeh, A.; Bognanni, A.; et al. Physical distancing, face masks, and eye protection to prevent person-to-person transmission of SARS-CoV-2 and COVID-19: A systematic review and meta-analysis. Lancet 2020, 395, 1973-1987. [CrossRef]

23. Eikenberry, S.E.; Mancuso, M.; Iboi, E.; Phan, T.; Eikenberry, K.; Kuang, Y.; Kostelich, E.; Gumel, A.B. To mask or not to mask: Modeling the potential for face mask use by the general public to curtail the COVID-19 pandemic. Infect. Dis. Model. 2020, 5, 293-308. [CrossRef]

24. Chughtai, A.A.; Seale, H.; Macintyre, C.R. Effectiveness of cloth masks for protection against severe acute respiratory syndrome coronavirus 2. Emerg. Infect. Dis. 2020, 26, e200948. [CrossRef] [PubMed]

25. Clase, C.M.; Fu, E.L.; Ashur, A.; Beale, R.C.L.; Clase, I.A.; Dolovich, M.B.; Jardine, M.J.; Joseph, M.; Kansiime, G.; Mann, J.F.E.; et al. Forgotten Technology in the COVID-19 Pandemic: Filtration Properties of Cloth and Cloth Masks-A Narrative Review. Mayo Clin. Proc. 2020, 95, 2204-2224. [CrossRef]

26. Konda, A.; Prakash, A.; Moss, G.A.; Schmoldt, M.; Grant, G.D.; Guha, S. Aerosol Filtration Efficiency of Common Fabrics Used in Respiratory Cloth Masks. ACS Nano 2020, 14, 6339-6347. [CrossRef]

27. Zangmeister, C.D.; Radney, J.G.; Staymates, M.E.; Vicenzi, E.P.; Weaver, J.L. Hydration of hydrophilic cloth face masks enhances the filtration of nanoparticles. ACS Appl. Nano Mater. 2021, 2694-2701. [CrossRef]

28. Lee, K.-P.; Yip, J.; Kan, C.-W.; Chiou, J.-C.; Yung, K.-F. Reusable Face Masks as Alternative for Disposable Medical Masks: Factors that Affect their Wear-Comfort. Int. J. Environ. Res. Public Health 2020, 17, 6623. [CrossRef]

29. EN 14683:2019+AC:2019. Available online: https://standards.cen.eu/dyn/www /f?p=204:110:0::::FSP_LANG_ID,FSP_PROJECT: 25,69675\&cs=146B5F75B099801AE4FF26267B7F9EEE1 (accessed on 9 February 2021).

30. Community Face Coverings_-Guide to Minimum Requirements, Methods of Testing and Use. Available online: https://www. cencenelec.eu/research/cwa/documents/cwa17553_2020.pdf (accessed on 9 February 2021).

31. Karuppasamy, K.; Obuchowski, N. Comparison of Fit for Sealed and Loose-Fitting Surgical Masks and N95 Filtering Facepiece Respirators. Ann. Work Expo. Health 2021. [CrossRef] [PubMed]

32. Xu, M.; Lee, P.; Collins, D. The critical importance of mask seals on respirator performance: An analytical and simulation approach. PLoS ONE 2021, 16, e0246720. [CrossRef]

33. Allison, A.L.; Ambrose-Dempster, E.; Aparsi, T.D.; Bawn, M.; Arredondo, M.C.; Chau, C.; Chandler, K.; Dobrijevic, D.; Hailes, H.; Lettieri, P.; et al. The environmental dangers of employing single-use face masks as part of a COVID-19 exit strategy. UCL Open Environ. Prepr. 2020. [CrossRef]

34. Mascara Cirurgica [Surgical Mask]. Available online: https://www.kuantokusta.pt/search?q=mascaracirurgica (accessed on 9 February 2021).

35. Makki, F.; Lamb, A.; Moukaddem, R. Plastics and the coronavirus pandemic: A behavioral science perspective. Mind Soc. 2020. [CrossRef]

36. Klemeš, J.J.; Van Fan, Y.; Jiang, P. The energy and environmental footprints of COVID-19 fighting measures—PPE, disinfection, supply chains. Energy 2020, 211, 118701. [CrossRef] [PubMed]

37. Shruti, V.C.; Pérez-Guevara, F.; Elizalde-Martínez, I.; Kutralam-Muniasamy, G. Reusable masks for COVID-19: A missing piece of the microplastic problem during the global health crisis. Mar. Pollut. Bull. 2020, 161, 111777. [CrossRef]

38. Coronavirus Disease (COVID-19) Advice for the Public: When and How to Use Masks. Available online: https://www.who.int/ emergencies/diseases/novel-coronavirus-2019/advice-for-public/when-and-how-to-use-masks (accessed on 9 February 2021). 
39. Vanapalli, K.R.; Sharma, H.B.; Ranjan, V.P.; Samal, B.; Bhattacharya, J.; Dubey, B.K.; Goel, S. Challenges and strategies for effective plastic waste management during and post COVID-19 pandemic. Sci. Total Environ. 2021, 750, 141514. [CrossRef]

40. Parashar, N.; Hait, S. Plastics in the time of COVID-19 pandemic: Protector or polluter? Sci. Total Environ. 2021, 759, 144274. [CrossRef]

41. Corburn, J.; Vlahov, D.; Mberu, B.; Riley, L.; Caiaffa, W.T.; Rashid, S.F.; Ko, A.; Patel, S.; Jukur, S.; Martínez-Herrera, E.; et al. Slum Health: Arresting COVID-19 and Improving Well-Being in Urban Informal Settlements. J. Urban Health 2020, 97, 348-357. [CrossRef] [PubMed]

42. Sangkham, S. Face mask and medical waste disposal during the novel COVID-19 pandemic in Asia. Case Stud. Chem. Environ. Eng. 2020, 2, 100052. [CrossRef]

43. Silva, A.L.P.; Prata, J.C.; Duarte, A.C.; Soares, A.M.V.M.; Barceló, D.; Rocha-Santos, T. Microplastics in landfill leachates: The need for reconnaissance studies and remediation technologies. Case Stud. Chem. Environ. Eng. 2021, 3, 100072. [CrossRef]

44. Arkatkar, A.; Arutchelvi, J.; Bhaduri, S.; Uppara, P.V.; Doble, M. Degradation of unpretreated and thermally pretreated polypropylene by soil consortia. Int. Biodeterior. Biodegrad. 2009, 63, 106-111. [CrossRef]

45. Muenmee, S.; Chiemchaisri, W.; Chiemchaisri, C. Microbial consortium involving biological methane oxidation in relation to the biodegradation of waste plastics in a solid waste disposal open dump site. Int. Biodeterior. Biodegrad. 2015, 102, 172-181. [CrossRef]

46. Hamzavi, I.H.; Lyons, A.B.; Kohli, I.; Narla, S.; Parks-Miller, A.; Gelfand, J.M.; Lim, H.W.; Ozog, D.M. Ultraviolet germicidal irradiation: Possible method for respirator disinfection to facilitate reuse during the COVID-19 pandemic. J. Am. Acad. Dermatol. 2020, 82, 1511-1512. [CrossRef]

47. Yalcin, I.; Sadikoglu, T.G.; Berkalp, O.B.; Bakkal, M. Utilization of various non-woven waste forms as reinforcement in polymeric composites. Text. Res. J. 2013, 83, 1551-1562. [CrossRef]

48. Battegazzore, D.; Cravero, F.; Frache, A. Is it Possible to Mechanical Recycle the Materials of the Disposable Filtering Masks? Polymers (Basel) 2020, 12, 2726. [CrossRef] [PubMed]

49. Jain, S.; Yadav Lamba, B.; Kumar, S.; Singh, D. Strategy for repurposing of disposed PPE kits by production of biofuel: Pressing priority amidst COVID-19 pandemic. Biofuels 2020. [CrossRef]

50. Ouhsine, O.; Ouigmane, A.; Layati, E.; Aba, B.; Isaifan, R.; Berkani, M. Impact of COVID-19 on the qualitative and quantitative aspect of household solid waste. Glob. J. Environ. Sci. Manag. 2020, 6, 41-52.

51. Ammendolia, J.; Saturno, J.; Brooks, A.L.; Jacobs, S.; Jambeck, J.R. An emerging source of plastic pollution: Environmental presence of plastic personal protective equipment (PPE) debris related to COVID-19 in a metropolitan city. Environ. Pollut. 2021, 269, 116160. [CrossRef] [PubMed]

52. Okuku, E.; Kiteresi, L.; Owato, G.; Otieno, K.; Mwalugha, C.; Mbuche, M.; Gwada, B.; Nelson, A.; Chepkemboi, P.; Achieng, Q.; et al. The impacts of COVID-19 pandemic on marine litter pollution along the Kenyan Coast: A synthesis after 100 days following the first reported case in Kenya. Mar. Pollut. Bull. 2021, 162, 111840. [CrossRef]

53. Zambrano-Monserrate, M.A.; Ruano, M.A.; Sanchez-Alcalde, L. Indirect effects of COVID-19 on the environment. Sci. Total Environ. 2020, 728, 138813. [CrossRef]

54. Cordova, M.R.; Nurhati, I.S.; Riani, E.; Nurhasanah; Iswari, M.Y. Unprecedented plastic-made personal protective equipment (PPE) debris in river outlets into Jakarta Bay during COVID-19 pandemic. Chemosphere 2021, 268, 129360. [CrossRef]

55. Rasmussen, G. Those COVID-19 masks, gloves and wipes we're all using are polluting land and sea. CBC, 9 June 2020.

56. Aragaw, T.A. Surgical face masks as a potential source for microplastic pollution in the COVID-19 scenario. Mar. Pollut. Bull. 2020, 159, 111517. [CrossRef] [PubMed]

57. Li, L.; Zhao, X.; Li, Z.; Song, K. COVID-19: Performance study of microplastic inhalation risk posed by wearing masks. J. Hazard. Mater. 2021, 411, 124955. [CrossRef]

58. Andrady, A.L. The plastic in microplastics: A review. Mar. Pollut. Bull. 2017, 119, 12-22. [CrossRef] [PubMed]

59. Jeong, J.; Choi, J. Adverse outcome pathways potentially related to hazard identification of microplastics based on toxicity mechanisms. Chemosphere 2019, 231, 249-255. [CrossRef] [PubMed]

60. Samuel, J.; Smaldone, G.C. Reducing leakage of surgical masks. In Proceedings of the American Thoracic Society 2018 International Conference, San Diego, CA, USA, 18-23 May 2018; p. B49.

61. Riutord-Sber, P.; de Pedro Gómez, J.E.; Pereira, T.C.; López-Safont, N.; García, I.; Jiménez, J.; Almoar-Velasco, P.J.; PaubliniOliveira, H.J.; Dominguez-Pérez, J.; González-Carrasco, D.; et al. An innovative, reusable and sustainable face-seal device to improve protection efficacy of surgical masks against COVID-19. Med. Balear 2020, 35, 9-21.

62. Improve the Fit and Filtration of Your Mask to Reduce the Spread of COVID-19. Available online: https://www.cdc.gov/ coronavirus/2019-ncov/prevent-getting-sick/mask-fit-and-filtration.html\#improve-fit (accessed on 22 March 2021).

63. Chowdhury, M.A.; Joshi, M.; Butola, B.S. Photochromic and Thermochromic Colorants in Textile Applications. J. Eng. Fiber. Fabr. 2014, 9, 155892501400900. [CrossRef]

64. Ji, D.; Fan, L.; Li, X.; Ramakrishna, S. Addressing the worldwide shortages of face masks. BMC Mater. 2020, 2, 9. [CrossRef] [PubMed]

65. Instituto de Medicina Molecular. Portugal Develops the First Textile Face Mask That Inactivates the SARS-CoV-2. Available online: https: / imm.medicina.ulisboa.pt/news/portugal-develops-the-first-textile-face-mask-that-inactivates-the-sars-cov2/\#intro (accessed on 22 March 2021). 
66. Das, O.; Neisiany, R.E.; Capezza, A.J.; Hedenqvist, M.S.; Försth, M.; Xu, Q.; Jiang, L.; Ji, D.; Ramakrishna, S. The need for fully bio-based facemasks to counter coronavirus outbreaks: A perspective. Sci. Total Environ. 2020, 736, 139611. [CrossRef] [PubMed]

67. Gorrasi, G.; Sorrentino, A.; Lichtfouse, E. Back to plastic pollution in COVID times. Environ. Chem. Lett. 2021, 19, 1-4. [CrossRef]

68. Ma, Q.; Shan, H.; Zhang, C.; Zhang, H.; Li, G.; Yang, R.; Chen, J. Decontamination of face masks with steam for mask reuse in fighting the pandemic COVID-19: Experimental supports. J. Med. Virol. 2020, 92, 1971-1974. [CrossRef]

69. ASTM Standards \& COVID-19. Available online: https://www.astm.org/COVID-19/ (accessed on 9 February 2021).

70. Lista de Máscaras Comunitárias Aprovadas [List of Approved Community Masks]. Available online: https://www.citeve.pt/c_ mascaras_aprovadas (accessed on 9 February 2021).

71. Coronavirus Disease (COVID-19): Masks. Available online: https://www.who.int/news-room/q-a-detail/coronavirus-diseasecovid-19-masks (accessed on 9 February 2021).

72. O fim de uma máscara é o início de algo. The end of a mask is the beginning of something. FreePass Guimarães, 15 January 2021.

73. Coronavirus: More Montreal Communities Adopting PPE Recycling. Available online: https://globalnews.ca/news/7498244/ coronavirus-ppe-recycling-montreal/ (accessed on 9 February 2021).

74. Disposable Face Masks Zero Waste Box. Available online: https://www.terracycle.com/en-GB/zero_waste_boxes/disposableface-masks-en-gb (accessed on 9 February 2021).

75. Israeli Company Turns Coronavirus Masks into Recyclable Thermoplastic. Available online: https://www.jpost.com/healthscience/israeli-company-turns-coronavirus-masks-into-recyclable-thermoplastic-650095 (accessed on 9 February 2021). 